Original Article

\title{
Flu pandemics: homeopathic prophylaxis and definition of the epidemic genius
}

\author{
Renan Marino \\ Faculty of Medicine of São José do Rio Preto, FAMERP, São Paulo, Brazil
}

\begin{abstract}
Recent studies on viral genetics establish swine-H1N1 - responsible for the ongoing pandemics as a remainder or continuation of the agent causing the flu epidemics of 1918. This study aimed at analyzing whether this common etiology also result in significant correlations of clinical manifestations. To do so, data were collected to compare the clinical evolution of cases in the 1918 and 2009 epidemics. This historical revision was the ground for evaluating the response to treatment including homeopathy in the former epidemics. It is discussed the convenience of including homeopathic prophylaxis grounded on the diagnosis of the epidemic genius among public health actions.
\end{abstract}

Keywords: Homeopathy; Collective health; Epidemics; Influenza A - H1N1.

\section{Introduction}

The Italian term Influenza was first used in 1743 to indicate the probable etiology ("Influenza del freddo": Influence of coldness) of a respiratory illness that fast affected a large number of people during the winter. Grippe (French), Greifen (German), Flu (English) and Cripu (Russian) are used to designate this universal, severe pandemic infectious disease that bursts out after irregular and relatively long periods of time (20-40 years or more). [1]

Recent data indicate that ongoing Hog Flu actually had its epicenter in the United States in 1918 from where it spread to Europe to become known as Morbus ibericus or Spanish Flu. Its viral etiology could only be established in 1933, when Smith, Andrews and Laidlaw were able to verify Koch's postulates reproducing the picture of flu in ferrets and white mice after nasal instillation of clinical materials of human origin. [2]

The new subtype of Influenza virus A-H1N1 was classified by the CDC (Center for Disease Control) as A/California/04/2009, a representative of a triple rearrangement of human, aviary and swine genes. [3] Genetic analysis of isolated California virus showing the direct relationship between swine variant H1N1 and the 1918 epidemics certainly results in clinical developments and implications that are discussed below. [4]

\section{Characteristic symptoms of Influenza A-H1N1 then and now: piecing the puzzle together}

Retrospective studies show that pandemic cycles present high mortality in their remission or second wave, which appears 6 months - 1 year after the occurrence of the initial, and usually moderated, cases [5]. Regarding the clinical manifestations observed during the Spanish Flu, our reference are the archives researched by Coutinho [1], which include the detailed description of signs and symptoms that he classified as described in Table 1.

The search for common points can be achieved from the comparison of the clinical characteristics of the former epidemics as described above and the clinical manifestations of the ongoing epidemics as described in June 
2009. To do so, data supplied by SINAN (Information System of Disease Notification) of the Brazilian Ministry of Health (MS) were analyzed, using as sample 378 confirmed cases of severe acute respiratory syndrome due to Influenza A-H1N1 occurring until the epidemiologic week 29/2009. [6] As relevant, we highlighted sudden fever of $39^{\circ} \mathrm{C}$, with dry and continual cough leading to intense dyspnea and facial cyanosis, chills, general muscle and joint pain, besides contuse headache, extreme prostration fast progressing into cardiovascular failure with hypotension and shock.

Table 1: Symptoms of Spanish Flu [1]

\begin{tabular}{|l|l|}
\hline $\begin{array}{l}\text { Stage/ Organs or } \\
\text { systems affected }\end{array}$ & Synoptic description of signs and symptoms of human Influenza, 1918 \\
\hline Prodrome & $\begin{array}{l}\text { Lassitude, the body feels as after prolonged and exhausting exertion, with physical } \\
\text { and mental depression, sudden high fever and intense headache. Joints and } \\
\text { muscular pain, mainly in the calves and lumbar area, sweating and morbiliform } \\
\text { rash in 30\% of cases. }\end{array}$ \\
\hline $\begin{array}{l}\text { Eyes and } \\
\text { rhinopharynx }\end{array}$ & $\begin{array}{l}\text { Frequent sneezing with nasal obstruction and discharge, dryness and itch in the } \\
\text { throat with dry, whooping, frequent and painful cough. Slight catarrhal } \\
\text { conjunctivitis, pale face and cyanosis around the mouth; frequent epistaxis. }\end{array}$ \\
\hline $\begin{array}{l}\text { Respiratory and } \\
\text { thorax }\end{array}$ & $\begin{array}{l}\text { Lung congestion especially in the base, bilateral, with dyspnea due to intense } \\
\text { bronchospasm, intense whooping-like cough with hemoptysis. }\end{array}$ \\
\hline Gastrointestinal & $\begin{array}{l}\text { Hiccups, nausea and incoercible vomiting, sialorrhea, abdominal pain around the } \\
\text { navel with mucous/bloody diarrhea. }\end{array}$ \\
\hline Neurological & $\begin{array}{l}\text { Headache, vertigo, neuralgia; modification of the level of consciousness in different } \\
\text { degrees, mental confusion, torpor, somnolence. }\end{array}$ \\
\hline
\end{tabular}

In order to manage data arising from different sources and to better understand the global dimension of the clinical parameters of the pandemics, we included the report of 18 Mexican cases from which 7 died (39\%), where there was fever, cough and dyspnea in 100\% of cases, sudden onset (72\%), hemoptysis (33\%), hypotension and hypoventilation (more than 50\%), stressing furthermore the occurrence of diarrhea only in children (22\%). Lymphocytopenia with less than 1,000 cells (61\%), increase of CPK (creatine phosphokinase) (72\%) and LDH (lactate dehydrogenase) (100\%) were the main laboratory parameters verified. [7]

We also sought to define the 5 main risk factors among the Brazilian population, on the grounds of the 222 patients monitored until epidemiologic week 28/2009/MS/SINAN [8]: 1) pregnancy - representing the group with higher mortality risk associated with hemorrhagic phenomena, placental abruption, hypoventilation and shock; 2) lung disease; 3) arterial hypertension; 4) heart disease; 5) immune depression.

The clinical comparison of Spanish Flu (1918), Mexico (2009) and Brazil (2009) makes evident the strict correlation of symptoms among them, a fact of high relevance as it also allows making a retrospective evaluation of the outcomes of homeopathic treatment between 1918 and 1920 which can supply reliable criteria to face the ongoing pandemics.

\section{Foundations of homeopathic prophylaxis}

Preventive use of homeopathy was first applied in 1801 during an epidemics of scarlet fever in Königslütter, Germany, when Samuel Hahnemann - the founder of homeopathy - prescribed a single dose of Belladona, as the remedy of the epidemic genius to susceptible children in the town with $100 \%$ success [9]. Homeopathic prophylaxis is grounded on the ability of homeopathic remedies to avoid or attenuate manifestations of disease when chosen according to the principle of similarity. According to authors such as Trousseau and Tetau it is also grounded on the notion of "terrain" and inheritance that would include the set of individual 
factors related to the constitution, predisposition and refractoriness to disease and metabolism[10]. Eizayaga sustains that homeopathic remedies increase individual unspecific resistance to infections, whereas nosodes increase specific immunity regarding definite etiologic agents[11]. Ullman attributes the prestige of homeopathy in Europe and the United States in the $19^{\text {th }}$ century to its success in the treatment of epidemics. [12]

\section{Antecedents of the use of homeopathy in the pandemics Influenza A-H1N1 (1918)}

Pandemics continued to cause high mortality in the 20 $0^{\text {th }}$ century: the Spanish Flu claimed 20-40 million victims, the Asiatic Flu - H2N2 (1957), 1 million and the Hong Kong Flu - H3N2 (1968), 700 thousand. [13]

In this study, we restricted historical revision of the use of homeopathy in epidemics to pandemics of human Influenza. As sources, we employed Winston's major study on the use of homeopathy in 1918 epidemics [14], while establishing as criteria the selection of rigorously verified data - through historic and scientific documents and ratified by official sources - we focused on Dewey's paper (cited in Winston) [15], published in 1921 in the Journal of the American Institute of Homeopathy with the title "Homeopathy in Influenza: A Chorus of Fifty in Harmony".

At that time, Dewey was professor of materia medica and therapeutics at Michigan University, which acquainted him with academic standards, so that he recorded with utmost care data highly significant for our research as exhibited in Table 2 .

Table 2: Data mentioned by Dewey

\begin{tabular}{|l|l|l|l|}
\hline \multicolumn{4}{|c|}{ Cases of human Influenza treated with homeopathy in 1918} \\
\hline Source & Place & Total number of patients & Mortality rate \\
\hline Pearson, W. A. & Philadelphia & 26.795 & $1,05 \%$ \\
\hline 30 doctors from several cities & Connecticut & 6.602 & $1 \%$ \\
\hline Wieland, F. & Chicago & 8.000 & $0,01 \%$ \\
\hline $\begin{array}{l}\text { Sappington, E. F. } \\
\text { (Homeopathic Medical Society) }\end{array}$ & $\begin{array}{l}\text { District of Columbia } \\
\text { (Washington) }\end{array}$ & 50.000 & $0,01 \%$ \\
\hline McCann, T.A. & Dayton, Ohio & 1.000 & $0 \%$ \\
\hline
\end{tabular}

Outcomes of patients treated with homeopathy are remarkable, especially when compared with those of patients treated exclusively with conventional remedies, as e.g. a group of 24,000 patients in Ohio, where mortality was $28.2 \%$. It is particularly noteworthy the comment of F. Wieland, from Chicago, on the use of Gelsemium during the epidemics, which according to him "was virtually the only remedy prescribed" [16].

Hughes' contribution: a map leading to the "eye of the hurricane", or how to actually find the epidemic genius 
Although to find the epidemic genius repertory analysis of the most remarkable, rare, strange and peculiar symptoms present in most cases during an epidemics may have some success, it is needed to resist the seduction of simple arithmetic additions, as this perhaps is the chief reason of mistakes in the diagnosis of the epidemic genius.

Richard Hughes, a leading representative of 19th century homeopathy believed that the selection of a remedy ought not to be grounded only on subjective symptoms, but rather on the characteristic nucleus of the symptomatic picture that was mandatorily expressed in the pathological effects experimentally verified in human beings and animals [17]. By the same token, he sustained that together with the principle of similarity, also pathology ought to be taken into account. For this reason, between 1884 and 1890, with the collaboration of Dake, he subjected the homeopathic materia medica to revision and depuration, which resulted in his 4-volume A Cyclopaedia of Drug Pathogenesy. Besides excluding purely clinic symptoms he emphasized provings conducted with low dilutions, i.e. below $6 \mathrm{cH}$ in order to obtain highly reliable data [17].

"Hughes' filter" - a tool seeking to ensure that the selected remedy is necessary and sufficient to pharmacologically minimize the physiopathology of an illness sought to prevent or heal - is extremely useful when candidates for epidemic genus are many, as in the case of the ongoing flu epidemics, were possible remedies include Aconitum napellus, Bryonia alba, Eupatorium perfoliatum, Influenzinum, Phosphorus and Rhus toxicodendron among others besides Ipecacuanha. Application of "Hughes' Filter" results in the peremptory indication of Ipecacuanha, on the grounds of the unmistakable specificity of its pattern of medicinal dynamics as it is shown below.

\section{Grounds for the diagnosis of Ipecacuanha as epidemic genius in the ongoing Influenza A-H1N1 pandemics}

Data on Ipecacuanaha agree among the different sources of the homeopathic materia medica beginning from Hahnemann's initial Fragmenta de viribus medicamentorum... published in 1805 [18]. Phatak's materia medica was selected as an example to deepen the study of the general action of this remedy, which includes: continual nausea, hemorrhages and frightening respiratory disturbs always accompanying most symptoms, such as bleeding gastrointestinal disorders; severe prostration with alteration of the level of consciousness; seizures and tetanus-like spasms complete the picture of symptoms. [19] It must be highlighted that aggravation occurs by both cold and heat, whereas this extraordinary hypersensitiveness to extreme modalities of temperature [20], although uncommon, has a direct relationship to the persistence of cases of Influenza A-H1N1, even in the lack of low temperatures, which leads us to conclude that these are instances not only of "Influenza del freddo" but also of "Influenza del caldo", manifesting a recently acquired ability of the present time mutant virus.

Regarding the high mortality rate among pregnant women, Phatak highlights profuse hemorrhages gushing out, with nausea, tachypnea, constant abdominal pain in the hypogastrium, stitches from the navel to the uterus, placenta previa and uterine prolapse.

The objective sequence of symptoms composing the physiopathologic and pathogenetic picture of Ipecacuanha must be seen as a dynamic picture, comprehending the extension of symptoms such as intense headache from the nape to the root of the tongue, with sensation as from a wound, as if the head had been beaten by blows, with nausea and cold sweating on the face, constriction of the chest and the larynx, with incessant, exhausting and violent cough at each breath, which makes the patient become stiff and cyanotic on the face, with uncontrollable hemoptysis, extenuated and almost unconscious, febrile and often evolving to bronchopneumonia, shock and death [19]. 
For reasons we ignore, Ipecacuanha is not listed anymore among the best remembered remedies by homeopaths. However, it was included in the first list of 24 polycrest remedies made by Hahnemann, i.e. remedies "which have many indications" [10].

\section{The contribution of experimentation of Ipecacuanha in animals}

Uraoga, ou Cephaelis ipecacuanha Swartz (Figure 1) is a plant native to center-west Brazil; a small shrub of 20-40 cm height, its chemical composition includes catechols (ipecacuanic acid), nitrogen heterosides, glycoproteins with allergenic properties and mainly about $3 \%$ isoquinoline alkaloids, among which emetine (60-75\%). Its active principles are mainly concentrated in the dried root, which is the part used in the preparation of the remedy [21].

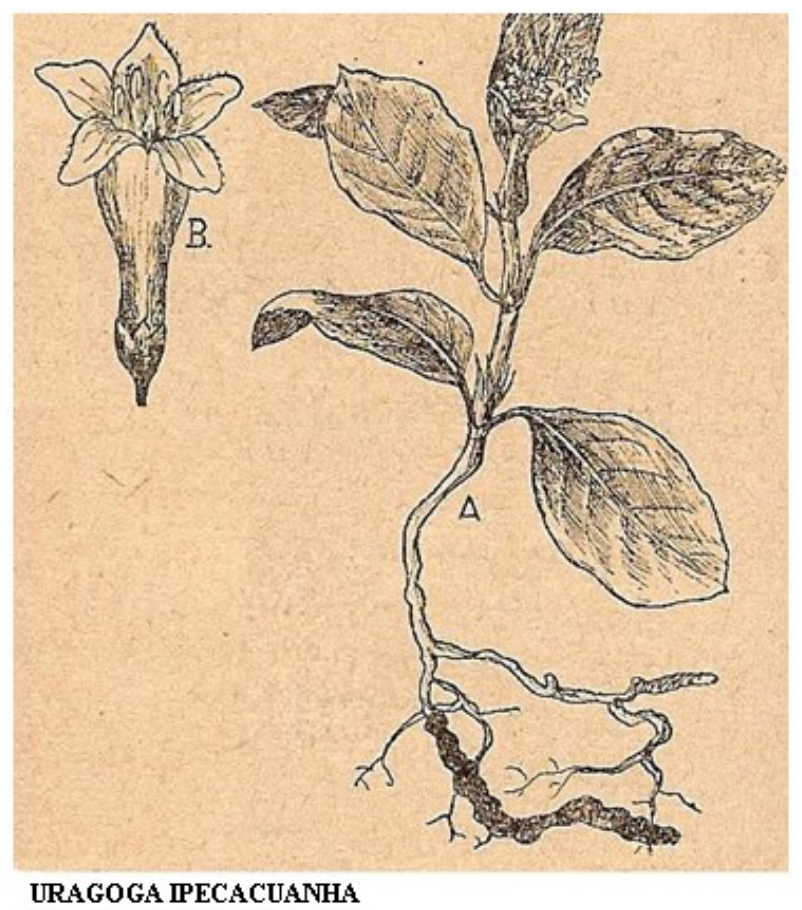

\section{A) PLANT \\ B) FLOWER}

Figure 1: Uragoga Ipecacuanha [22]

Records of experimentation of Ipecacuanha in animals (frogs and rabbits) mainly express disorders attributed to emetine, such as hemorrhage, depression of the myocardium, pulmonary congestion, pneumonia and vomiting, among others. [23] (Figure 2) 
III. Experzments on animals.--I. Dr. Polichronie (Thèse de Paris, 1874) has made a series of researches.for the purpose of discovering the mode of action of Ip. and of emetine. His conclusions are as follows:

a. Emetine is the really active principle of Ip.

b. Emetine is á very toxic substance. It kills animals in two ways, sometimes by the prostration of the nervous system which it causes, sometimes - whien given in small doses-by the intense enteritis which it brings on.

c. Emetine brings on vomiting only at the moment of its elimination by the gastric mucous membrane, as proved by the delay of the sickness, and even more frequently its entire absence, after section of the two vag ; in this respect it acts quite differently from apomorphia and tartar emetic, these causing vomiting as quickly when the nerves are cut as when they are intact.* ii, 59.)

d. Emetine has no vaso-constrictor action. (Liond. Med. Record,

2. PÉCHOLIER, in his experiments, employed emetine as weil as the drug itself. The animals selected for experiment were rabbits and frogs,- the former because they do noc vomit. The following are the results of the inquiry:

a. I. considerably diminished the number and energy of the pulsations of the heart in rabbits.

b. It notably reduced the number of respirations in these animals, as well as the afflux of blood to the lung. Indeed, the pale and exsanguine state of the pulmonary tissue displayed after death was remarkable; it was a veritable depletion of the lung.

c. In animals under its influence the temp. of mouth, axilla, and ear was lowered; while that of rectum remained stationary or rose.

d. In the digestive sphere, Ip. produced efforts at vomiting; hyperamia of alimentary canal, and disappearance of sugar from liver.

c. The action on the nervous system was investigated in frogs. It reduced promptly the energy of the nervous system; and determined considerable collapse. The paralysis induced by it showed itself chiefly in the sensory system, motbr nervous power and muscular irritability were merely diminished and not wholly abolished. (Lancet, Apri] 25th; 1863.)

3. My experience of the effects of emetine is at variance on some points with that of M. Pécholier. An my cases the respiratory movements were increased in frequency and the cardiac action was not less rapid than in health. In the lungs there was always, post mortem, more or less engorgement with blow pneumonia was set up (DYce Dück Wertr, St. Barth. Hosp. Rep., $v, 220$.

* The same results have been obtained by Chouppe (Gaz. Méd. de Paris, Aug. ist, 1874 ).-EDs.

Figure 2: Records of experimentation of Ipecacuanha in animal [23]. 


\section{Validity of the use of homeopathic complexes in epidemics}

Use of remedies synergically associated in epidemics constitutes an interesting resource and besides acknowledged by experienced practitioners, it is justified in order to widen the scope of action resulting in higher effectiveness [10]. Therefore, in the current circumstance, it seems pertinent to add to Ipecacuanhaselected as epidemic genius - a second remedy arising from the application of the criterion of etiopathogenic similarity, viz. nosode Influenzinum - in fact nosode of H1N1 would be better indicated. Despite it is prepared from antigenic variant H2N2 (Asiatic Flu, 1958), it is still indicated according to Kent's remark in Lection XXIX: "prophylaxis requires a lesser degree of similarity than the one needed to heal" [24].

Gelsemium sempervirens can also be added, as a complementary of Ipecacuanha [25] in order to strengthen the effect of the prescription during the prodrome, increasing in this way the prophylactic value of the complex.

Moreover, in a paper presented to the I Panamerican Congress of Homeopathy in 1977 dealing with "Prophylaxis of infectious diseases in the first months of life with homeopathic nosodes", Castro mentioned that during the 1918 flu epidemics, Gelsemium was the epidemic genius, whereas during the 1957 epidemics, Influenzinum prepared by Nelson Laboratory in London was prescribed with success [26].

Table 3 describes more details of the abovementioned remedies.

Table 3: Basic data of the remedies included in the complex [27]

\begin{tabular}{|c|c|c|}
\hline Influenzinum (nosode) & Gelsemium sempervirens & Ipecacuanha \\
\hline $\begin{array}{l}\text { Source: } \\
\text { Flu vaccination prepared by } \\
\text { Pasteur Institute, consisting } \\
\text { in a mixtre of } 3 \text { parts of } \\
\text { culture of Asian virus A- } \\
\text { Singapour I-1957 and } 1 \text { part } \\
\text { of culture of European virus } \\
\text { APR-8 }\end{array}$ & $\begin{array}{l}\text { Source: } \\
\text { Fresh rhizome. } \\
\text { Original habitat: } \\
\text { North America } \\
\text { Famíly: Loganiaceae } \\
\text { Vulgar names: Yellow } \\
\text { Jessamine, Evening } \\
\text { Trumpetflower }\end{array}$ & $\begin{array}{l}\text { Source: } \\
\text { Dry root collected before blossoming. } \\
\text { Original habitat: Brazil } \\
\text { Famíly: Rubiaceae } \\
\text { Scientific name: Cephaelis ipecacuanha } \\
\text { Swartz }\end{array}$ \\
\hline Pathogenetic trial [33] & Pathogenetic trial [34] & Pathogentic trial [35] \\
\hline
\end{tabular}

Regarding indications found in homeopathic repertories related to the use of Influenzinum, Gelsemium sempervirens and Ipecacuanha in Influenza, we found mentions in Boericke [28] and Farias Dias [29].

\section{Conclusions}


Prejudice or ignorance are not valid reasons to rule out homeopathic prophylaxis as an adjuvant tool in the fight against resurgent epidemics but conversely, rejection implies in dismissing logic, evidence and scientific neutrality itself.

The scope and effectiveness of application of homeopathy in collective health has been strongly hinted at, more recently in the control of dengue in Macaé, Rio de Janeiro and São José do Rio Preto, São Paulo, Brazil [32].

The Brazilian health system is in state of alert facing the impact of the flu pandemics; to approach successfully this crisis it is legitimate to include the homeopathic model in the strategy adopted by the Ministry of Health.

In public health, when a homeopathic remedy is preventively prescribed in single doses, the choice of the dilution is a significant technical factor, strictly dependent on the projected repetition of the medicinal stimulus. In the current condition, for the effect of the stimulus to last at least 3 months, the most indicated dilution is $12 \mathrm{cH}$.

\section{References:}

[1] Coutinho E. Tratado de Clínica das Doenças Infectuosas e Parasitárias. Rio de Janeiro: Livraria Pimenta de Mello \& C; 1939.

[2] Bier O. Bacteriologia e Imunologia. 18 ${ }^{\text {th }}$ ed. São Paulo: Edições Melhoramentos; 1977.

[3] US Centers for Disease Control and Prevention. Swine-origin influenza A-H1N1 virus infections in a school - New York City. MMWR. 2009 Apr; 58 (Dispatch): 1-3.

[4] Mossad SB. The resurgence of swine-origin influenza A (H1N1). Cleve Clin J Med. 2009; 76(6): 337-343.

[5] Jordan EO. Epidemic influenza: A survey. Chicago: American Medical Association; 1927.

[6] Secretaria de Vigilância em Saúde. Informe Epidemiológico: Influenza A (H1N1). 2 nd ed. [cited 2009 jul]. Available from: www.portal.saude.gov.br/portal/arquivos/pdf/informe influenza a h1n1 3107 2009.pdf.

[7] Padilla RP, Zamboni DR, Leon SP, Hernandez M, Falconi FQ, Bautista E, Venegas AR, Serrano JR, Ormsby CE, Corrales A, Higuera A, Mondragon E, Villalobos JAC. Pneumonia and Respiratory Failure from Swine-Origin Influenza A (H1N1) in Mexico. N Engl J Med. 2009; 361(7): 680-689

[8] Boletim Eletrônico Epidemiológico. Situação epidemiológica da nova influenza A (H1N1) no Brasil, Influenza - Edição Especial. 2009 Jul 23; Ano 09: $\mathrm{n}^{\mathrm{o}}$ 02. Available from: www.portal.saude.gov.br/portal/arquivos/pdf/boletim_epidemiologico_influenza_23_072009.pdf

[9] Hahnemann S. Organon da arte de curar. 6 ${ }^{\text {th }}$ ed. Ribeirão Preto: Museu de Homeopatia Abrahão Brickmann; 1996.

[10] Kossak-Romanach A. Homeopatia em 1000 conceitos. São Paulo: Elcid; 1984.

[11] Eizayaga FX. Tratado de Medicina Homeopática. $3^{\text {th }}$ ed. Buenos Aires: Ediciones Marecel; 1992.

[12] Ullman D. Homeopatia: medicina para o século XXI. São Paulo: Cultrix; 1988.

[13] Zimmer SM, Burke DS. Historical Perspective - Emergence of Influenza A (H1N1) Viruses. N Engl J Med. 2009 jul 16; 361(3): 279-285.

[14] Winston J. The Faces of Homeopathy: An Illustrated History of the First 200 Years. Tawa: Great Awk Publishing; 1998.

[15] Dewey WA. Homeopathy in Influenza: A Chorus of Fifty in Harmony. Journal of the American Institute of Homeopathy. 1921; 13: 1028-1043

[16] Grimes M. Important for Swine Flu Epidemic: Homeopathy Successfully Treated Flu Epidemic of 1918 [homepage]. 2009-[publish in 2009 Apr 28, cited 2009 Sep 21]. Available from: www.naturalnews.com/z026148_homeopathy_epidemic_flu_epidemic.html.

[17] Campbell A. As duas faces da homeopatia. Rio de Janeiro: Matéria Médica; 1991.

[18] Galhardo JER. Iniciação Homeopática. Rio de Janeiro: Typ E Sondermann; 1936. 
[19] Phatak SR. Matéria Médica de Medicinas Homeopáticas. New Delhi: B Jain Publishers; 1994.

[20] Duprat H. A Teoria e a Técnica da Homeopatia. Rio de Janeiro: Gráfica Olímpica Editora Ltda; 1974.

[21] Guermonprez M, Pinkas M, Torck M. Matière médicale homeopathique. Paris: Doin; 1985.

[22] Schultz A R. Introdução ao Estudo da Botânica Sistemática. 2 ${ }^{\text {nd }}$ ed. Porto Alegre: Livraria do Globo; 1943.

[23] Hughes R, Dake JP. Cyclopaedia of drug pathogenesy. Vol III. London/New York: British Homeopathic Society/Boericke \& Tafel; 1888 .

[24] Kent JT. Filosofia Homeopática - Trad de Ruth Kelson. São Paulo: Robe Editorial; 1996.

[25] Cairo N. Guia de Medicina Homeopática. 21 th ed. São Paulo: Livraria Teixeira; 1984.

[26] Castro D. Homeopatia e profilaxia. São Paulo: Cultrix; 1988.

[27] Soares AAD. Dicionário de Medicamentos Homeopáticos. São Paulo: Livraria Santos Editora; 2000.

[28] Boericke W. Repertório Homeopático do Dr. Boericke. $4^{\text {th }}$ ed em Português. Rio de Janeiro: Copyright Benjamim B Fraenkel; 1991.

[29] Dias AF. Repertório Homeopático Essencial. Rio de Janeiro: Cultura Médica; 2001.

[30] IPCC, 2007: Summary for Policymakers. In: Parry ML, Canziani OF, Palutikof JP, van der Linden PJ, Hanson CE, editors. Climate Change 2007: Impacts, Adaptation and Vulnerability. Contribution of Working Group II to the Fourth Assessment Report of the Intergovernmental Panel on Climate Change. Camvridge: Cambridge University Press. 2007. 7-22.

[31] Janeway Jr, Charles A. Imunobiologia: o sistema imunológico na saúde e na doença. $2^{\text {nd }}$ ed. Porto Alegre: Artes Médicas; 1997.

[32] Nunes LAS. Contribution of homeopathy to the control of an outbreak of dengue in Macaé, Rio de Janeiro. Int J High Dilution Res [online]. 2008 [cited 2009 Sep 22]; 7(25): 186-192. Available from: http://www.feg.unesp.br/ ojs/index.php/ijhdr/article/view/315/374.

[33] Cartier F. Traité complet de thérapeutique homéopathique. Paris: Baillière et fils; 1929.

[34] Douglas JS. West Journal of Homeopathy, 1: 1, 1853.

[35] Hahnemann CFS. Fragmenta de viribus medicamentorum positivis in sano corpore humano observatis, 2 teile. Leipzig: J A Barth; 1805.

\section{Pandemia de gripe: homeoprofilaxia e definição do gênio epidêmico}

\section{RESUMO}

Estudos recentes de genética viral estabelecem o vírus H1N1 suíno - responsável pela atual pandemia - como remanente ou continuação do agente que produziu a epidemia de gripe de 1918. Este estudo visou analisar se esta etiologia comum também se acompanha de correlação significativa das manifestações clínicas. Para tanto, foram coletados dados a fim de comparar a evolução clínica nos casos nas epidemias de 1918 e 2009. Esta revisão histórica foi a base para avaliar a resposta ao tratamento, incluindo o homeopático, na epidemia passada. Discute-se a conveniência de incluir homeoprofilaxia entre as medidas de saúde pública, com base no diagnóstico do gênio epidêmico.

Palavras chave: homeopatia; saúde coletiva; epidemias; influenza A-H1N1.

\section{Pandemia de gripe: profilaxis homeopática y definición del genio epidémico}




\section{RESUMEN}

Estudios recientes de genética viral establecen el virus H1N1 porcino - responsable por la pandemia actual como remanente o continuación del agente que provocó la epidemia de gripe de 1918. Este estudio buscó analizar si esta etiología en común también se acompaña por correlación significativa de las manifestaciones clínicas. Con este fin, fueron recogidos datos con el propósito de comparar la evolución clínica en casos de las epidemias de 1918 y 2009. Esta revisión histórica sirvió como base para evaluar la respuesta al tratamiento, incluyendo homeopatía, en la epidemia anterior. Se discute la conveniencia de incluir profilaxis homeopática entre las medidas de salud pública, basada en el diagnóstico del genio epidémico.

Palabras llave: homeopatia; salud pública; epidemias; influenza A-H1N1

\section{(cc)) BY-NC-ND Licensed to GIRI}

Support: authors declare that this study received no funding.

Conflict of interest: authors declare there is no conflict of interest.

Received: 01 September 2009; Revised 25 September 2009; Published: 30 September 2009.

Correspondence author: Renan Marino, renanmarino@uol.com.br.

How to cite this article: Marino R. Flu pandemics: homeopathic prophylaxis and definition of the epidemic genius. Int $\mathrm{J}$ High Dilution Res. 2009 [cited YYYY Month dd]; 28 (8): 100-109. Available from:

http://www.feg.unesp.br/ ojs/index.php/ijhdr/article/view/354/399. 